\title{
Some additions to the knowledge of Turkish Myxomycetes
}

\author{
MARJA HÄRKÖNEN
}

\begin{abstract}
HÄRKÖNEN, M. 1988: Some additions to the knowledge of Turkish Myxomycetes. Karstenia 27: 1-7.

In early summer 1983 Myxomycetes and bark of trees for later culture in moist chambers were collected in West Turkey. Altogether 21 species of Myxomycetes were found. The following 12 species are new to Turkey: Arcyria denudata (L.) Wettst., A. versicolor Phill., Ceratiomyxa fruticulosa (Müll.) Macbr., Collaria rubens (A. Lister) Nann.-Brem., Echinostelium elachiston Alexop., Hemitrichia clavata (Pers.) Rost., Lamproderma arcyrioides (Sommerf.) Rost., Physarum cinereum (Batsch) Pers., Stemonitopsis typhina (Wiggers) Nann.-Brem., Trichia alpina (R. E. Fries) Meylan, T. decipiens (Pers.) Macbr., T. favoginea (Batsch) Pers.
\end{abstract}

Marja Härkönen, Department of Botany, University of Helsinki, Unioninkatu 44, SF-00170 Helsinki, Finland

The Myxomycetes are a neglected group in the studies of Turkish fungi. Only one fairly thorough paper on Turkish Myxomycetes has been published (Härkönen \& Uotila 1983). According to it, 31 species of Myxomycetes are known from Turkey.

Students of botany from the University of Helsinki made a botanical excursion to West Turkey on May 14-28, 1983, under the leadership of Dr. Pertti Uotila and Mr. Arto Kurtto. The itinerary is given by Uotila and Kurtto (1984). I took part in the excursion in order to collect Myxomycetes.

The excursion route can be seen in Fig. 1. At the time of the excursion, it was summer in the lowlands of Turkey and, as very dry weather prevailed, no fruit bodies of Myxomycetes were found. In the mountain regions, it was still spring, the ground was very moist and several specimens of Myxomycetes were collected.

All the collecting localities (mostly used for sampling vascular plants) are shown in Fig. 1. Specimens of Myxomycetes or bark from living trees for later cultivation in moist chambers were collected from the following 18 localities.

11 C1 Izmir: Davutlar National Park, end of the road

Alt. sea level-20 m

4-6 $\mathrm{m}$ tall virgin macchia

May 17, 1983
12 C1 Muğla: W shore of the Bafa Gölü, yard of a restaurant

Alt. ca. $40 \mathrm{~m}$

May 17, 1983

15 C1 Muğla: By the main road Gökova-Marmaris, ca. $15 \mathrm{~km}$ from Marmaris

Alt. ca. $70 \mathrm{~m}$

Brook ravine with Liquidambar orientalis

May 17, 1983

16 C1 Mugla: Marmaris, ca. $4 \mathrm{~km} \mathrm{E}$ of Marmaris

Alt. ca. sea level

Brookside with temporarily inundated Liquidambar orientalis forest

May 18, 1983

18 C1 Mugla: Marmaris, near the town centre, in front of Hotel Halici

Alt. sea level

May 18, 1983

25 B3 Kütahya: Afyon-Kütahya, $32 \mathrm{~km}$ from Kütahya

Alt. $1200 \mathrm{~m}$

Juniperus excelsa-J. oxycedrus scrub

May 19, 1983

27 B3 Bilecik: By the road Kütahya-Bozüyuk; Otosan, ca. $4 \mathrm{~km}$ from Akpinar towards Kütahya

Alt. $880 \mathrm{~m}$

May 20, 1983 
Fig. 1. The excursion route in Turkey on May 14-28, 1983. Collection sites indicated by numbers.

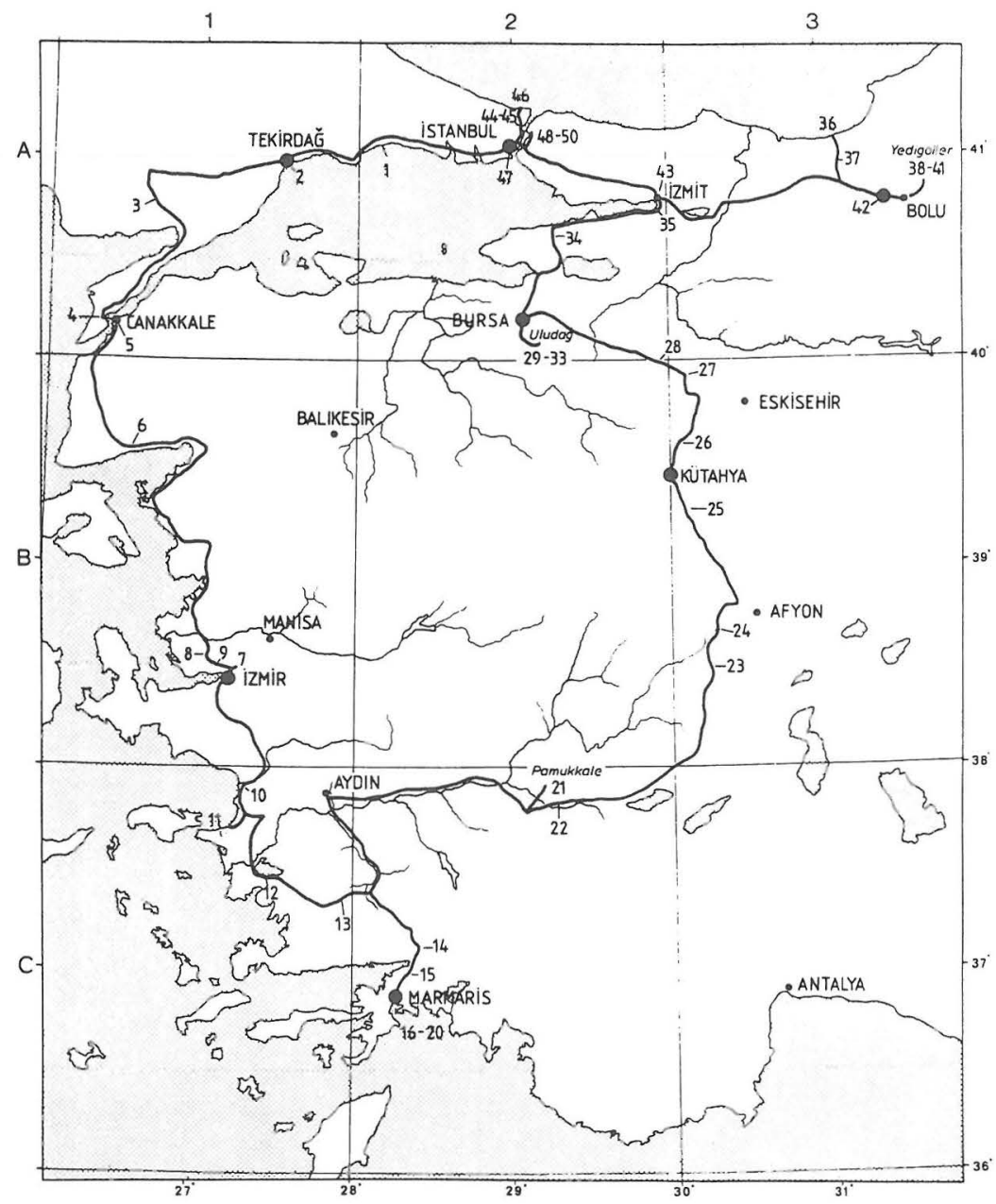

29 A2(A) Bursa: Uludag, S slope, by the road from Cekirke, ca. $5 \mathrm{~km}$ from Cekirke Alt. $410 \mathrm{~m}$

Mixed macchia and deciduous forest May 21, 1983

30 A2(A) Bursa: Uludag, S slope, by the main road ca. $10 \mathrm{~km}$ from Bursa

Alt. $780-800 \mathrm{~m}$

Pinus brutia-Castanea sativa-Quercus forest May 21, 1983

31 A2(A) Bursa: Uludag, by the gate of the National Park

Alt. ca. $1300 \mathrm{~m}$

Pinus nigra forest

May 21, 1983

32 A2(A) Bursa: Uludag National Park, by the main road just below the watering place (Deve- tasi piknik yeri)

Alt. $1600-1700 \mathrm{~m}$

Abies nordmanniana subsp. bornmuelleriana forest

May 21, 1983

33 A2(A) Bursa: Uludag National Park, above the hotel area

Alt. $1900-2100 \mathrm{~m}$

Open Abies nordmanniana subsp. bornmuelleriana forest with scattered Fagus on steep slope

May 21, 1983

34 A2(A) Istanbul: Orhangazi-Yalova, ca. $12 \mathrm{~km}$ $\mathrm{S}$ of Yalova, $\mathrm{S}$ of the road junction to Esadiye Alt. $200-260 \mathrm{~m}$

Deciduous forest in steep brook ravine May 22, 1983 
Table 1. List of Myxomycete specimens. For the numbers of localities, see page 2.

\begin{tabular}{|c|c|c|c|c|c|}
\hline & $\begin{array}{l}\text { Number of } \\
\text { specimens }\end{array}$ & Locality & Substrate & $\begin{array}{l}\text { Specimens } \\
\text { pH of the } \\
\text { substrate }\end{array}$ & $\begin{array}{l}\text { n moist chamber } \\
\text { Incubation time } \\
\text { in days }\end{array}$ \\
\hline Arcyria cinerea & 2 & 11,16 & $\begin{array}{l}\text { Bark of Pistacia } \\
\text { and Liquidambar }\end{array}$ & 5.5 & $19-34$ \\
\hline A. denudata & 1 & 38 & Decaying wood & & \\
\hline A. pomiformis & 4 & $16,18,44$ & $\begin{array}{l}\text { Bark of Washingtonia } \\
\text { and Quercus }\end{array}$ & $5-6$ & $3-6$ \\
\hline A. versicolor & 5 & 32,33 & $\begin{array}{l}\text { Decaying trunk of } \\
\text { Abies }\end{array}$ & & \\
\hline Ceratiomyxa fruticulosa & 1 & 40 & Decaying wood & & \\
\hline Collaria rubens & 1 & 18 & Bark of Washingtonia & 5.5 & 34 \\
\hline Echinostelium elachiston & 4 & $12,15,16$ & $\begin{array}{l}\text { Bark of Pinus } \\
\text { and Liquidambar }\end{array}$ & 5.5 & $6-13$ \\
\hline E. minutum & 7 & $12,29,31,39,44$ & $\begin{array}{l}\text { Bark of Pinus, Castanea } \\
\text { and Quercus }\end{array}$ & $4.5-5.5$ & $6-36$ \\
\hline Hemitrichia clavata & 3 & 38 & $\begin{array}{l}\text { Decaying wood, probably } \\
\text { of Fagus }\end{array}$ & & \\
\hline Lamproderma arcyrioides & 1 & 32 & $\begin{array}{l}\text { Litter on edge of melting } \\
\text { snow }\end{array}$ & & \\
\hline Licea kleistobolus & 3 & $11,25,30$ & Bark of Pinus & $4.5-5$ & $6-10$ \\
\hline Lycogala epidendrum & 3 & $38,39,41$ & $\begin{array}{l}\text { Fallen trunk of Fagus; } \\
\text { decaying wood }\end{array}$ & & \\
\hline Macbrideola cornea & 3 & 34 & Bark of Pistacia & $5-5.5$ & $10-27$ \\
\hline Paradiacheopsis fimbriata & 4 & 29,30 & $\begin{array}{l}\text { Bark of Castanea and } \\
\text { Pinus }\end{array}$ & $5-5.5$ & $3-7$ \\
\hline Perichaena corticalis & 1 & 27 & Bark of Malus & 6 & 6 \\
\hline Physarum auriscalpium & 1 & 16 & Bark of Liquidambar & 5.5 & 15 \\
\hline$P$. cinereum & 1 & 25 & Bark of Juniperus & 6.5 & 34 \\
\hline Stemonitopsis typhina & 2 & 38 & $\begin{array}{l}\text { Fallen trunk, probably of } \\
\text { Fagus }\end{array}$ & & \\
\hline Trichia alpina & 1 & 38 & $\begin{array}{l}\text { Fallen trunk, probably of } \\
\text { Fagus }\end{array}$ & & \\
\hline T. decipiens & 2 & 41 & Decaying wood & & \\
\hline T. favoginea & 2 & 31,40 & $\begin{array}{l}\text { Decaying wood; decaying } \\
\text { trunk of Pinus }\end{array}$ & & \\
\hline
\end{tabular}

38 A3 Bolu: ca. $23 \mathrm{~km}$ from Bolu to Yedigöller, highest point of the road

Alt $1680 \mathrm{~m}$

Open Abies nordmanniana subsp. bornmuelleriana-Fagus forest with patches of meadow May 23, 1983

39 A3 Bolu: Yedigöller National Park
Alt. ca. $800 \mathrm{~m}$

Carpinus-Fagus forest in bottom of the valley in surroundings of the lakes May 23, 1983

40 A3 Bolu: Ca. $20 \mathrm{~km}$ from Bolu to Yedigöller Alt. $1400 \mathrm{~m}$ Abies nordmanniana subsp. bornmuelleriana- 
Fagus forest on steep slope

May 23, 1983

41 A3 Bolu: Ca. $15 \mathrm{~km}$ from Bolu to Yedigöller

Alt. $1200 \mathrm{~m}$

Abies nordmanniana subsp. bornmuelleriana-

Fagus forest

May 23, 1983

44 A2(E) Istanbul: Belgrad forest, Neset suyu, around the picnic place

Alt. ca. $20 \mathrm{~m}$

Deciduous Quercus forest

May 25, 1983

The bark material was used later in summer in Finland to establish 81 moist chamber cultures. The moist chambers were treated in the same way as described by Härkönen and Uotila (1983). The cultures were maintained for five weeks, after which the nonproductive chambers were removed. No rewetting was done as earlier (Härkönen \& Uotila 1983) and this time the yield of Myxomycetes was smaller.

\section{The species of Myxomycetes}

The specimens of Myxomycetes found in the field during the excursion or later in the moist chambers totalled 53. They represent 21 species, 12 of which are new to Turkey. Representative specimens are deposited in the Botanical Museum of the University of Helsinki. The species are briefly discussed below. The notes on their distribution in the Mediterranean area and the areas around Turkey were compiled from Alexopoulos (1959), Almeida (1964, 1966, 1976, 1979, 1983), Brandza (1914, 1916, 1921, 1928), Faurel et al. (1965), Galán et al. (1984), Gràcia Barba (1977, 1979), Gràcia \& Llimona 1980), Gràcia et al. (1981, 1982), Ladó (1985a, b), Ladó \& Moreno (1976, 1978, 1980, 1981), Lado et al. (1980), Maire et al. (1926), Malençon \& Bertault (1967), Nannenga-Bremekamp \& Ladó (1985), Pidoplichka (1932), Pirola (1968), Pirola \& Credaro (1971, 1975), Rammeloo (1973), Ramon (1968), Vasjagina et al. (1977), Zerov (1967). The notes on the general distribution (whether a species is considered cosmopolitan or not) are from Martin and Alexopoulos (1969).

The collecting sites and substrata of all the specimens are listed in Table 1.

\section{List of species}

Arcyria cinerea (Bull.) Pers.
A. denudata (L.) Wettst.

One specimen from a mountain area. Cosmopolitan. New to Turkey.

\section{A. pomiformis (Leers.) Rost.}

A. versicolor Phill.

Several abundant specimens, all collected from a high mountain area (1600-2000 m) on fallen trunks of Abies nordmanniana subsp. bornmuelleriana. Not common, earlier records from the Mediterranean region are from Moldavia, Morocco and Spain. New to Turkey.

Ceratiomyxa fruticulosa (Müll.) Macbr.

A cosmopolitan species. New to Turkey.

Collaria rubens (A. Lister) Nann.-Brem.

Bark from Washingtonia palm in a moist chamber yielded a rich colony of small sporangia. Even under the dissecting microscope, the small collar formed by the persistent lower part of the peridium can be seen. According to Martin and Alexopoulos (1969), not uncommon in Britain but rarely collected elsewhere. In the Mediterranean area reported from Spain. New to Turkey.

Echinostelium elachiston Alexop.

Sporangia $150-220 \mu \mathrm{m}$, erect or nodding. Stalk hairlike, containing granular material in the lower portion and becoming hyaline upwards. The sporangia are very fragile and the spore ball tends to drop off when a preparation is made. No capillitium. Some sporangia seem to lack a columella, some have a ball at the top. It is difficult to decide, whether there is a sporelike columella or whether one of the spores remains at the top of the stalk after all the others have dispersed (see Alexopoulos 1959). When all the spores have dispersed, a small collar can be seen at the top of the sporangium. Spores hyaline, smooth or very finely warted, having faint circular areas on the wall, 6-8.5 $\mu \mathrm{m}$ in diameter.

The present specimens look very much like those described by Härkönen and Uotila (1983 Fig. 9) as Echinostelium sp. The only difference from the present material is in the spores, which in the earlier specimens have distinct circular thickenings at points of spore to spore contact. I cannot say whether this is a constant character, since attempts to cultivate the species from spore to spore were unsuccessful.

The type specimen of Echinostelium elachiston (GR-194, State University of Iowa, Myxomycete collection) was compared with the present specimens. As the type specimen includes only a few sporangia, only one preparation was made from it. Only the

Figs. 2-5. Capillitium and spores of four species of Trichiaceae collected in mountains in Turkey. - 2: Hemitrichia clavata (no. 3246). - 3: Arcyria denudata (no. 3236). - 4: A. versicolor (no. 3231). - 5: Trichia favoginea (no. 3244). 


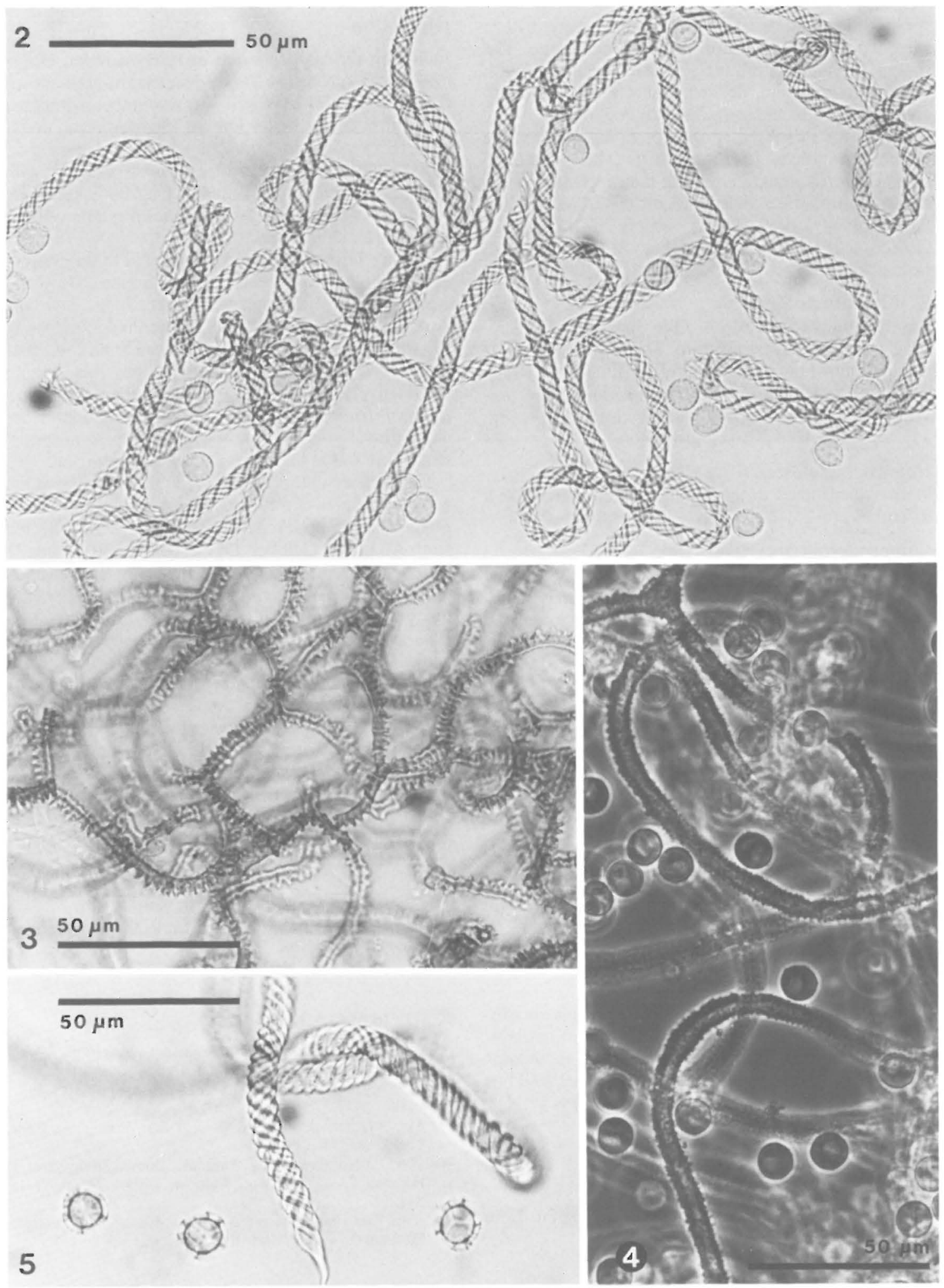


spore ball could be caught in it. The spore ball is surrounded by a very thin peridial membrane. The spores are hyaline, minutely warted (seen only with oil immersion lens), do not appear to have circular areas on the wall and are $6.5-8 \mu \mathrm{m}$ in diameter.

Of all the described species of Echinostelium, the present specimens fit E. elachiston best, although some of the sporangia are taller than indicated in the description of the species. According to Martin and Alexopoulos (1969), it is widely distributed in Greece, and it now seems to belong to the Turkish flora also.

\section{E. minutum de Bary}

Several typical specimens. One specimen has sporangia without any capillitium. The top of the stipe is rounded and one spore-like cell is stuck to it. Such sporangia occurred in Turkish material in the previous study as well (Härkönen \& Uotila 1983; Fig. 11). This may be a distinct new taxon.

Hemitrichia clavata (Pers.) Rost.

Widely distributed in the Mediterranean region. New to Turkey.

Lamproderma arcyrioides (Sommerf.) Rost.

Strongly iridescent sporangia on litter at the margin of melting snow. Reported from Greece, Italy, Portugal, Morocco and Kazakhstan. New to Turkey.

\section{Licea kleistobolus Martin}

Lycogala epidendrum (L.) Fries

Macbrideola cornea (G. Lister \& Gran) Alexop.

Paradiacheopsis fimbriata (G. Lister \& Gran) Hertel

Perichaena corticalis (Batsch) Rost.

Physarum auriscalpium Cooke

P. cinereum (Batsch) Pers.

A cosmopolitan species. New to Turkey.

Stemonitopsis typhina (Wiggers) Nann.-Brem. A cosmopolitan species. New to Turkey.

Trichia alpina (R.E. Fries) Meylan

Dark brown pulvinate sporangia and short plasmodiocarps. Spores minutely spinulose, $13-16 \mu \mathrm{m}$ in diameter. This species, which grows in high mountains near melting snow (Martin \& Alexopoulos 1969) has been reported from Morocco. New to Turkey.

T. decipiens (Pers.) Macbr.

A cosmopolitan species. New to Turkey.

T. favoginea (Batsch) Pers.

Widely distributed in the Mediterranean region. New to Turkey.

\section{Discussion}

Including the taxa reported in Härkönen and Uotila (1983), 43 species of Myxomycetes are now known from Turkey. This is still a low number compared with those of the better known Mediterranean countries. Eleven of the present species developed in moist chambers from dormant spores collected with bark and only ten were found as fruit bodies, in spite of intensive searching. More species might have been found on an autumn excursion.

Rather little attention has been paid to the phenology of the Myxomycetes in the literature. Gray and Alexopoulos (1968) reported that, June, July and August are the most favourable months for collecting Myxomycetes in the Northern United States, whereas in Jamaica year-round collecting is possible. During the relatively short fruiting season in the north, Ceratiomyxa fruticulosa and Lycogala epidendrum are almost invariably the first species to appear in spring. Both were found in Turkey during the excursion.

Bjørnekaer and Klinge (1963) have tabulated the collecting times of all the Danish Myxomycete specimens obtained so far. Most specimens were collected from August to October. Of the 102 species listed, 33 have been found at least once in spring (from March to May). The following species have particularly many spring finds Hemitrichia vesparium, Perichaena corticalis, Trichia persimilis, $T$. decipiens and $T$. varia. In Finland, the following Myxomycetes often appear in spring: Trichia persimilis, T. varia, $T$. decipiens, Arcyria nutans, A. incarnata, Comatricha nigra and Perichaena corticalis (Härkönen 1974). Species of Trichia and Arcyria were abundantly represented in the Turkish material also, and six of the ten species found in the field belong to the family Trichiaceae. On the other hand, one of these is $T$. decipiends, which Eliasson (1981) considers a species clearly restricted to autumn.

Acknowledgements. I want to thank Dr. Pertti Uotila for comments on the manuscript.

\section{References}

Alexopoulos, C.J. 1958: Three new species of Myxomycetes from Greece. - Mycologia 50: 52-56.

- 1959: Myxomycetes from Greece. - Brittonia 11: 25-40.

Almeida, M.G. 1964: Contribuição para o estudo dos Myxomycetes de Portugal. - Bol. Soc. Portuguesa Ciênc. Nat. 2a sér. 10: 172-185.

- 1966: Contribuição para o estudo dos Myxomycetes de Portugal 2. - Rev. Fac. Ciências Lisboa $2^{\mathrm{a}}$ sér. C 14: 5-12.

- 1976: Contribuição para o estudo dos Myxomycetes de Portugal 4. - Rev. Biol. 10: 113-125. 
- 1979: Contribuição para o estudo dos Myxomycetes de Portugal 5. - Rev. Biol. 11: 79-90.

- 1983: Contribuição para o estudo dos Myxomycetes de Portugal 6. - Rev. Biol. 12: 71-76.

von Bjørnekaer, K. \& Klinge, A. 1963: Die dänishen Schleimpilze. - Friesia 7: 149-296.

Brandza, M. 1914: Myxomycètes de Roumanie. - Ann. Sci. Univ. Jassy 8: 259-294.

- 1916: Note sur quelques Myxomycètes nouvelles pour la flore Mycologique de la Roumanie. - Ann. Sci. Univ. Jassy 10: 182-199, 2 pls.

- 1921: Troisième contribution a l'étude des Myxomycètes de Roumanie. - Ann. Sci. Univ. Jassy 11: 113-131.

- 1928: Les Myxomycètes de Neamtz (Moldavie). - Bull. Soc. Mycol. France 44: 249-299, 4 pls.

Faurel, L., Feldmann, J. \& Schotter, G. 1965: Catalogue des Myxomycètes de l'Afrique du Nord. - Bull. Soc. Hist. Nat. Afr. Nord 55: 7-35.

Eliasson, U. 1981: Patterns of occurrence of Myxomycetes in a spruce forest in South Sweden. - Holarctic Ecology 4: $20-31$.

Galán, R., Ladó, C. \& Ortega, A. 1984: Nuevos datos sobre Myxomycetes presentes en la provincia de Granada (España). - Acta Bot. Malacitana 9: 3-16.

Gràcia Barba, E. 1977: Contribución a la flora de mixomicetes de Cataluña. - Mediterranea 2: 79-87.

- 1979: Contribució al coneixement de la flora i distribució dels mixomicets a la Mediterrània occidental 1. Eivissa i Formentera (Pitiüses). - Folia Bot. Misc. Barcelona 1: $37-44$.

Gràcia, E., Honrubia, M. \& Ladó, C. 1982: Mixomicets nous o interessants per a la flora Ibèrica i Balear. Folia Bot. Misc. Barcelona 3: 95-99.

Gràcia, E., Honrubia, M. \& Llimona, X. 1981: Aportación al conocimiento de los hongos del SE de España 2. Mixomicetes de la provincia del Albacete. Anales Univ. Murcia, Ciencias 37: 63-79.

Gràcia, E. \& Llimona, X. 1980: Contribución al conocimiento de la flora y distribución de los mixomicetes en el Mediterráneo occidental 3. Sureste de España: Murcia. Anales Univ. Murcia, Ciencias 34: 3-21.

Gray, W. \& Alexopoulos, G.J. 1968: Biology of the Myxomycetes. - 288 pp. New York.

Härkönen, M. 1974: Über die finnischen Schleimpilzen. Karstenia 14: 54-81.

Härkönen, M. \& Uotila, P. 1983: Turkish Myxomycetes developed in moist chamber cultures. - Karstenia 23: $1-9$.

Ladó, C. 1985a: Estudios sobre Myxomyctes. 6. - Anales Jard. Bot. Madrid 42: 9-23.

- 1985b: Estudios sobre Myxomycetes 7. - Bol. Soc. Micol. Castellana 10: 19-26.

Ladó, C. \& Moreno, G. 1976: Contribución al estudio de los Myxomycetes en España peninsular 1. - Anales Inst. Bot. Cavanilles 33: 111-124.

- 1978: Contributión al estudio de los Myxomycetes en España peninsular 2. - Anales Inst. Bot. Cavanilles 34: $401-415$.

- 1980: Contributión al estudio de los Myxomycetes en España peninsular 3. Provincia de Madrid. - Anales Jardin Bot. Madrid 37: 5-30.

- 1981: Contributión al estudio de los Myxomycetes en la peninsula Iberica 4. Pais Vasco. - Munibe 33: 63-78.

Ladó, C., Moreno, G., Ortega, A. \& Calonge, F.D. 1980: Estudios sobre Myxomycetes 4. Provincia de Granada. - Bol. Soc. Micol. Cast. 5: 55-68.
Maire, R., Patouillard, N. \& Pinoy, E. 1926: Myxomycètes de l'Afrique du Nord. - Bull. Soc. Hist. Nat. Afr. Nord 17: 38-43.

Malençon, G. \& Bertault, R. 1967: Champignons du Maroc. - Bull. Soc. Sci. Nat. Phys. Maroc 47: 237-281.

Martin, G.W. \& Alexopoulos, C.J. 1969: The Myxomycetes. $-560 \mathrm{pp}$. Iowa City.

Nannenga-Bremekamp, N.E. \& Ladó, C. 1985: Notes on some Myxomycetes from Central Spain. - Proc. K. Nederl. Akad. Wetenschappen (6) 88: 219-231.

Pidoplichka, M. 1932: Kritichni materijali do flori miksomitsetiv Ukraini. Sur la flore des myxomycètes de l'Ukraine. - Zhurn. Biobot. Tsiklu VUAN 3-4: 69-102.

Pirola, A. 1968: Una lista di mixomiceti Italiani. Giornale Bot. Italiano 102: 21-32.

Pirola, A. \& Credaro, V. 1971: Contributo alla flora Mixomicetologica Italiana. - Giornale Bot. Italiano 105: 157-165.

- 1975: Tentativo di inquadramento sinecologico di mixomiceti italiani. - Not. Fitosoc. 10: 111-130.

Rammeloo, J. 1973: Contribution à la connaissance des Myxomycètes du Maroc (1re not). - Bull. Soc. Sci. Nat. Phys. Maroc. 53: 31-35.

Ramon, E. 1968: Myxomycetes of Israel. - Israel J. Bot. 17: 207-211.

Uotila, P. \& Kurtto, A. (eds.) 1984: Helsingin yliopiston kasvitieteen laitoksen Turkin retki 1983. - Helsingin yliop. kasvit. lait. mon. 90: 1-63.

Vasjagina, M.P., Byzova, Z.M. \& Golovenko, I.N. 1977: Nizshie griby i miksomitsety (Phycomycetes et Myxomycetes). - Flora Spor. Rast. Kazakhstana 10: 1-348. Alma-Ata.

Whitney, K.D. 1980: The Myxomycete genus Echinostelium. - Mycologia 72: 950-987.

Zerov, D.K. (ed.) 1967: Viznachnik gribiv Ukraini 1. 254 pp. Kiev.

Accepted for publication

on October 15, 1987 